\title{
Regimen Used to Treat Malignant Anal Neoplasm
}

National Cancer Institute

\section{Source}

National Cancer Institute. Regimen Used to Treat Malignant Anal Neoplasm. NCI

Thesaurus. Code C159439.

Any regimen that can be used for the treatment of anal carcinoma. 